Olga Bilobrovets

Zhytomyr Ivan Franko State University, Ukraine

\title{
Transformation of stereotypical perception of „the image of Poles" in the Russian Empire society during the World War I
}

\begin{abstract}
The cohabitation of different nations in the border of one state creates certain ethnic, social, mental collective nation's image which changes very slowly. These processes are enhanced during the global historical processes with significant devastating effects which lead to an alteration in public consciousness.

During World War I, under the influence of the external crisis circumstances, the necessity to take into account the strategic interests and fundamental values of the nations involved in the war, led to a change in perception of the image of the Pole. The image of a Pole as a disloyal person to Russian statehood had changed into the image of a true confederate in the mutual striving with the enemy.

Perception of the Poles as partners in state-building and international cohabitation became possible only due to global geopolitical changes, the policy of powerful nations, including the Polish territory and the ability of Polish political powers to consolidate their efforts around the idea of statehood restoration.
\end{abstract}

Keywords

Russian Empire, the image of the Pole, loyalty, World War I. 


\section{Introduction}

The cohabitation of different nations in the border of one state always has its own features caused, among other things, by their status, historical circumstances and conditions of development. It creates an ethnic, social and mental collective image of people in public perception. As well as a change of mentality and other spiritual lines of nations, the established social image changes slowly and can be seen over a considerable period of time.

Both Ukrainian and foreign scientists ${ }^{1}$ provided research of the social position of the different groups of Polish population and its social-economic changes on Ukrainian lands in the $19^{\text {th }}$ to the early $20^{\text {th }}$ century and during World War I.

The transformation of the worldview settings of society in the Russian empire, its perception of the Polish population during World War I, the changes of the geopolitical situation and the new order of international relations, are all under research consideration.

The change of the stereotypical public perception and image of certain nations happens usually in extreme crises, when the possibility to show up its other qualities appear. Usually people's behaviour, its representative groups becomes consonant to the power policy.

\section{2. "The image of the Poles" as an enemy of the state in the early 20th century and before World War I}

After the loss of their state, Poles became part of the population of other states. Their numbers added up to nearly 20 million: 50\% were under the Russian control, 20\% in Austria, 20\% in Prussia and 10\% in America. ${ }^{2}$ The largest amount of Poles was concentrated on Right-Bank Ukraine after its accession to the Russian Empire in the late 18th century. Therefore, the traits and the image of Poles emerge most strongly there. In Russian and Ukrainian societies, the image of a Pole was widespread, foremost, as a large landowner, nobleman, enemy

${ }^{1}$ D. Bovua, Bytva za zemlyu v Ukrayini 1863-1914 rr.: Polyaky v sotsio-etnichnykh konfliktakh, Kyyiv 1998; O. Kalakura, Polyaky v etnopolitychnykh protsesakh na zemlyakh Ukrayiny u XX st., Kyyiv 2007; M. Korzeniowski, Za Złotą Bramą: działalność spoleczno-kulturalna Polaków w Kijowie w latach 1905-1920, Lublin 2009.

${ }^{2}$ L. Bylski, Rzut oka na kwestię polska w dobie obecnej, Krakow 1910. 
of Russian authority, because of which Poles lost their own state. A significant number of Polish nobility retained their privileges in the Russian Empire, but formed the image of a potential enemy. This image was considerably strengthened after the Polish uprisings in 1830-1831 and 1863. The Tsar's government started a policy of repressions and assimilation of the Polish population of the empire, transforming them into loyal citizens of the Russian state. Moreover, four fifths of the Polish nobility was declassed, a ban was issued forbidding Poles to purchase land, and besides, educational and cultural restrictions were also introduced. ${ }^{3}$

Big landowners were more willing to compromise, so to preserve their rights and privileges. The development of capitalism became a reason of the appearance of opposite tendencies in social and political life. Poland's dependence on the Tsar's Russia, the fight of state bureaucracy against Poles, the economic competition between Russian (Moscow) and Polish (Lodz) industrial districts promoted the development of Polish nationalism and solidified the image as enemy. A catholic clergy that stood on the defence of "Polish patriotism» played a considerable role. From the other point of view, the development of capitalism assisted in the appearance of antinationalistic tendencies, among bourgeoisie and workers.

It caused a boom in Polish industry, which was related to the Russian markets, by the close combination of interests of the Polish capitalism with that Russian, with the purpose of the receipt of governmental subsidies, and also the general fight of the Polish and Russian workers, against capitalists and tsarism. ${ }^{4}$

However, not a single layer of Polish society - neither nobility, nor intellectuals, nor peasants, nor workers ever stopped to fight for their rights and privileges, hoping for self-government and restoring their own statehood.

That's why the image of a Pole - as public enemy - still existed. As a proof of this, one can find correspondence, reports of the provincial gendarmerie departments, that controlled and supervised Polish organizations and individuals. During the so-called "organic work" in the second half of the 19th century, there were legal and secret groups of students, including the „Corporation”, which existed in Kyiv, Zhytomyr and Bila Tserkva. ${ }^{5}$ After the bourgeois revolution in 1905, the rise in activity of Polish NGOs, with nationalist orientation came

3 TsDIAK Ukrayiny) f. 442, op. 821, spr. 291, ark. 49-53.

41905 r.w Polsce: zbiur artukuluw, Moskwa 1926.

${ }^{5}$ J. Chmielewski, Pierwshe lata korporacji studentów polaków w Kijowie (1884-1892), Warszawa 1939. 
about. These NGOs included such as, „Polonia”, „Corporation”, „Union of Poles” and others. ${ }^{6}$

The numerous Polish intellectuals became a good expression of ideas of nationalism. This became the most important reason for leaving public service. In fact, in Russia and Poland, it was the Russians who equally occupied all higher and secondary public positions. For intellectuals there was some place in industry and trade, although, there was high competition with Jews, who were growing in number. ${ }^{7}$

Urban bourgeoisie, average wealthy landowners, intellectuals and the majority of the clergy became united by a nationally oriented party - "Narodowa Democratia (Endeky)", headed by Roman Dmowski. The party criticized the policy of loyalty and cooperation with the Tsarist government, but was nevertheless ready to cooperate with everyone to achieve territorial unification of Polish lands in one state and to restore its statehood. ${ }^{8}$

By 1905, the labour movement was in hiding and had a number of secret organizations. After the bourgeois revolution of 1905-1907, activities of legal workers began, and a new type of revolutionary leaders, the so-called "The working intelligentsia”, appeared and was to replace the old „bourgeois intellectuals”. Clubs of workers began to appear, and later on were replaced by cultural and educational societies, sick-leave funds and trade unions. ${ }^{9}$ The interests of workers were defended by the Polish Socialist Party, the nationalist section of which was led by J. Pilsudski. ${ }^{10}$

Particular attention was paid to provinces close to the border. Under suspicion, in the first place, were those Poles who were active in public life and had a significant political and economic influence on others. In July 1914, the Governor of Podil, in a report to Kiev Governor-General pointed out that Count J. Potocki visited Kamianets, and this visit coincided in time with the announcement of the ultimatum from Germany to Serbia. In one of the neighbouring villages there was a meeting between the Polish landowners on determining the position of the Polish society towards Russia, in case of complications with Austria. The Commander of the army issued an order to

\footnotetext{
6 TsDIAK Ukrayiny, f. 274, op. 1, spr. 3134, ark. 18-45.

71905 r.w Polsce: zbiór artykulów, Moskwa 1926.

8 J. Urszyn, Wojna i polska sprawa, „Klosy Ukrainskie” 9-10 (1914), p. 9-10.

9 TsDIAK Ukrayiny, f. 278, op. 1, spr. 26, ark. 318.

10 TsDIAK Ukrayiny, f. 274, op. 1, spr. 2441, ark. 364.
} 
send a company of soldiers urgently to the estate of Count Potocki in Antoniny for a general search, whilst maintaining secrecy. ${ }^{11}$

A group of Poles who fell under the attention of the Gendarmerie department of Volyn province in July 1914, lived near the residence of Army troops of the Southwestern Front. Among these Poles, from the list reported to the Kiev governor-general, there were the nobles - Juliusz Kraczkiewicz, Dr. Stanisław Peszynski, pharmacist Alexander Domanski and a member of Berdichev powiat rural council, Ivan Stolyhvo. It was also noted that "the mentioned above people are certainly dangerous to the interests of the state and so they must be sent from the specified district". Their unreliability was based on their previous activity. Nobleman Kraczkowski previously secretly ran a Polish school and because of this was brought to justice. He was characterized as "malicious Polish nationalist". Dr. Peszynski was a head of the society "Osvita", closed by government, and a member of the "Berdichev charitable society of help to the poor". According to reports of the gendarmes, he spoke out for active steps against Russia and the alliance with Austria. He was a supporter of "Jagiellonian idea", which was the restoration of Poland "from sea to sea". The owner of a pharmacy in the city Berdichev Alexander Domanski received the label of a "staunch Pole-separatist" for the support of the nationalist movement in the district and for collecting funds for it. The Polish nobleman Stolyhvo also belonged to this movement. As a result of all this, the suspects were arrested and sent to Vyatka province. ${ }^{12}$

In the reports of the Chief of Volyn Gendarmerie, pharmacist of Kupel A. Krzyrzanowski, Dr. A. Lipski and priest B. Orent were recognized as doubtful personalities, and according to rumours aspired to the victory of Austria and discussed it at their meetings. The search gave no positive results and therefore they were left at large. ${ }^{13}$

In the list of "politically unreliable persons and enemies of the Russian state" in late July 1914, a group of Poles was reported. This group was headed by Count J. Tyszkiewicz with his wife Irene, who lived in Berdichev powiat of Kiev province. In addition, they were the members of the society "Osvita", which was closed by the government. The commander-in-chief of the armies of the Southwestern Front insisted on their arrest and deportation under the police surveillance to Ufa province as "bad elements". However, Kyiv's Governor-

11 TsDIAK Ukrayiny, f. 442, op. 864, spr. 234, ark. 1-5.

12 TsDIAK Ukrayiny, f. 442, op. 864, spr. 234, ark. 21-28.

13 TsDIAK Ukrayiny, f. 442, op. 864, spr. 234, ark. 45. 
-General in reply said that ordinary members of the group - landowners Leonti Rogozinski, Sigismund Zemenski, Erasm Dalewski and others could be sent to Poltava Province, and Count J. Tyszkiewicz could be left in his Berdichev powiat under secret police surveillance.

The reason for such a decision was that "their actions should not cause a special feeling of anger of the Poles". In the decree of the head of the Kiev Provincial Gendarme Department (PGD) it was noted that the course of events of world importance in the life of the peoples of Europe was dictated by the will of the leader of Russian people, proceeded quickly and changed their meaning. Among the acts of extreme importance there should be attributed the appeal of the Supreme Commander, Grand Duke Nicholas "To the Poles", who "despite of still hostile attitude to the Russian state and law, but were present allies to liberated Slavic peoples from the oppression of Germanism". ${ }^{14}$

\section{Poles in the Russian Empire were allies of imperial power in the First World War}

This decision became the beginning of change in the attitude of state bureaucratic machinery, mass media and Russian society towards the Poles, which was caused by the events of World War I.

However, the image of superior, arrogant and haughty people stuck to Poles. This caused irritation among most people of both higher and lower strata of the empire. Thus, the head of the Kiev provincial gendarmerie department indicates absinthism of Poles and their "self-conceit”, referring to the refusal of Polish lawyers of Kyiv on April 1, 1916 to participate in the banquet on the formation of Jury Committee attorney of Kyiv Trial Chamber, when their nominated candidate was not elected to head the Council Peresvit-Soltan. ${ }^{15}$ Another typical case demonstrates a sense of superiority of Poles. In Vasylkiv county for agricultural work, in October 1916, 40 Polish prisoners of war were sent. They differed from others because they kept apart as a group; they performed work properly but were arrogant towards local villagers. One of them started a conflict with a Ukrainian, calling him „cattle". ${ }^{16}$

\footnotetext{
14 TsDIAK Ukrayiny, f. 442, op. 864, spr. 234, ark. 75-76.

15 TsDIAK Ukrayiny, f. 274, op. 4, spr. 456, ark. 80.

16 TsDIAK Ukrayiny, f. 274, op. 5, spr. 56, ark. 82.
} 
The situation changed when the World War I began. Poles, who were between three warring states, had a chance and a hope to obtain their own self-government and even more - independence. The „Polish question” became burning and each of the countries that was involved in the war - Russia, Germany and Austria-Hungary - hoped for the support of the Polish population and that is why they were promised with autonomy after the victory in the war.

This explains why Poles had a huge rise of patriotism in the Russian Empire at the beginning of the war. The general enthusiasm increased after the Grand Duke's decree, the Supreme Commander Nicholas, which appeared on August 1, 1914 , and stated that the Poles have the right to self-government. Poles in cities organized demonstrations in support of the Russian army and massively entered its ranks. On August 3, a statement of Polish parties that they support Russia in war, appeared in press. Poles of Zhytomyr sent a congratulatory telegram to the Supreme Commander, signed by 250 prominent people with hope for the revival of Poland, the reconciliation of brother peoples and faith in the victory of Russian arms. ${ }^{17}$

After that appeal „To the Poles” the head of Lutsk and Zhytomyr Catholic diocese the prelate A. Bajewski appealed to the clergy of his diocese with a circular. In this circular he urged the clergy and the people to pray to God for the victory of Russia and the allied countries, to avert all misfortunes of the war and the quickest restoration of peace. On August 3, 1914 in Zhytomyr, a solemn prayer service took place in the Catholic church. This service was led by the secretary of diocese J. Zagurski. In addition, all the Catholic clergy took part and prayed for the health of the entire tsarist family, the Supreme Commander of the Russian army Grand Duke Nicholas with wishes of glorious victory to Russian troops. ${ }^{18}$

The Polish press, printed a declaration about the willingness to serve in the Russian army and support the Russian authorities in their common fight against the enemy, first in Warsaw, and then spread in other cities of Russia. Numerous articles appeared in the press stating the leading idea of the joint struggle of two Slavic peoples against Germanism and hoping that "raising its

17 Polyaky y voyna. Zayavlenye pol'skykh party, „ZHizn’ Volyni”, 206 (1914), p. 3.

18 Torzhestvennoe molebstvye v rymsko-katolycheskom kafedral'nom sobore, „ZHizn' Volyni”, 201 (1914), p. 3. 
arms valiant Russian army also fights for the sacred revival of Poland united under the sceptre of the Russian Tsar". ${ }^{19}$

Besides statements of Polish politicians and public figures in press supporting Russian troops, they contributed concrete material help. A large landowner from Podil, Michał Sobański, gave 100000 rubles to the Supreme Commander, "calling for God's blessing on the Grand Duke for his compassion and to help wounded soldiers as he personally decides". ${ }^{20}$

In a secret report from the Head of Kyiv PGD in early August 1914, about the attitude of the Polish population, it was indicated that the appeal "To the Poles" had a great impact on the Polish population and in this regard, he highlighted certain groups that characterized the attitude of Poles to the current events. The largest group of Poles considered themselves lucky that the future power and unification of Poland "is accompanied not with its sons' blood, which are dying in the uprisings, but loyalty to the Russian government".

Quite a large group of Poles, the so-called "Russian orientated ones", considered that Poland could only achieve independence based on some strong country, which recently they thought Austria to be, but after "a new direction of Russian domestic policy" was proclaimed, such a state became Russia. This group also felt that they should organize militia parties inside the Empire to protect the population from bandits and looters, as well as to defend the rights of Poles and to be engaged in propaganda among the Polish peasants. ${ }^{21}$

Under this new situation the attitude towards Poles in the public mind started to change. One common goal - victory over the enemy - made Poles of the Russian Empire ally in the fight, and this increased respect and some appreciation for such a position. Using the situation, Polish political circles, led by Democrat Roman Dmowski and deputies of the State Duma, had repeatedly raised the issue of autonomy of Poles after the war. In July 1915 the Russian-Polish commission was created to work out the project of the future autonomy of Poles. One of its variants was presented by Count S. Welopolski and supported by the deputies of the State Duma such as M. Harusevych, Raczkowski from the Polish community and others. ${ }^{22}$

19 Otvet polyakov na vozzvanye Verkhovnoho Hlavnokomanduyushcheho, „ZHizn' Volyni” 8 (1914), p. 3.

${ }^{20}$ Krupnyiy zemlevladelets Podolii, „ZHizn’ Volyni”, 202 (1914), p. 3.

21 TsDIAK Ukrayiny, f. 442, op. 864, spr. 239, ark. 301.

22 Zajavlenie polyakow, „ZHizn’ Volyni”, 18 (1916), p. 3. 
In the course of the war, with its large number of victims and destruction, scepticism of the Poles towards promises of the Russian authorities grew, but they did not lose hope for autonomy and thus kept their loyalty towards the Russian country.

\section{The process of changing the attitude of society towards Poles}

The process of changing the attitude towards Poles in society took place in connection with the crisis and the tragic circumstances during the war, but it was still slow. The imperial way of thinking did not allow, first of all, government and the top of society, to perceive Poles as a self-governing nation in its own imperial state. An example of such an opinion is the discussion of the autonomy of Poland, when the majority of the Duma factions, both right and left, found it inconvenient to give many rights to Poles because "Russian society and the State Duma must stand for freedom, national self-determination of the Russian people in historically Russian Western lands" ${ }^{23}$

A difficult process towards the development of the perception of Poles as partners with the Russian society began as a minority in the future state with a coexistent autonomy. The subsequent occupation of the Kingdom of Poland and Warsaw, the fact that Germans gave to Poles the rights to use the Polish language in schools and universities, the establishment of self-government made the relations between the Russian liberal circles and Polish society get worse, which was reflected in the press. The following year, at the second anniversary of the appeal "To the Poles" proclaimed by Supreme commander, a lot of materials in press appeared, that added tension in society and Russian-Polish relations.

The Polish newspaper in Kyiv "Dziennik Kijowski", which was the main way to express ideas of national democratic camp, from year to year, was getting more critical towards the Russian government in view of their attitude towards the Polish issue. The Chief Editor of "Dziennik Kijowski", Edward Paszkowski, in the front page article "The constant misunderstanding", in the summer 1916,, wrote that the Russian liberal society recognized the Poles and their desire for unification and self-government, but "the Polish people continue to be treated

\footnotetext{
${ }^{23}$ Kotmene ogranicheniy dlya polyakov, „ZHizn’ Volyni”, 56 (1916), p. 3.
} 
as a nation, and Poland as an ethnographic unit, united as the "Kingdom of Poland", which is a creation of the Russian state-building". ${ }^{24}$

Poles believed that a general formula for the solution of the Polish issue could be created and worked out through a concrete program. However, the Ministry of Internal Policy headed by Nikolay Maklakov did not do it. The State Council in July 1915, the Russian Prime Minister Ivan Goremykin instructed the Council of Ministers to work out a draft project of autonomy of Poland, but concrete work on it was not carried out. In February 2,1916 the Prime Minister, Boris Stürmer, in the State Duma confirmed that the government could not specifically describe the issue.

Even though they did not come to an agreement on a single project of approval of Polish autonomy, Russian liberals still required from Poles to give up the rights granted to them by the Germans in occupied territories. Professor Nikolay Yastrebov, in a long article in the newspaper "Birzhevyie viedomosti”, wrote that "Poles should give up rights, introduced in the Kingdom of Poland by Germans, and expect them from Russians". 25

\section{The transition of Polish society to the standpoint of the struggle for state independence}

Starting from autumn 1916, in Polish society, on the contrary, an atmosphere yearning for independence started to spread, and in the Polish press the word "independence" started to sound clearly. Besides, the State Duma deputy, a Pole, Lubomir Dymsza, stated the same in Moscow after a meeting on refugee issues. He was asked how he would see the future of Poland, he said that "only not autonomous. Russia is always late. Previously, I only dreamed of autonomy and did not want anything more. Now, after all the horrors of war and the destruction of the Kingdom of Poland, after constant disappointment and many cases, when Russia doesn't fulfill its promises, I see the only solution of the Polish issue is a creation of an independent Polish Kingdom. Russia has not learned to respect the rights of autonomous regions, as an example - Finland". ${ }^{26}$

\footnotetext{
${ }^{24}$ E. Paszkowski, Nieporozumienie stale, „Dziennik Kijowski”, 211 (1916), p. 1.

${ }^{25}$ E. Paszkowski, Nieporozumienie stale, „Dziennik Kijowski”, 211 (1916), p. 1.

26 TsDIAK Ukrayiny, f. 274, op. 5, spr. 56, ark. 82.
} 
Among the political and social forces of Russia were those representatives who consistently were against giving national minorities any rights, such as big landowners and the bourgeoisie, united in the Octobrist Party. Middle and small bourgeoisie, the intelligentsia was represented by the party of constitutional democrats, or cadets, headed by Petr Miliukov. As liberals, they supported giving to minorities, "capable state building", to the Poles and Finns, the possibility of obtaining autonomy, but opposed their independence and separation. Miliukov declared this position at a meeting with the British Sir Edward Gray in July 1916 when the Russian Duma delegation was in England. This position was also supported by the British side. ${ }^{27}$

The situation between the Polish and Russian political and social forces was getting worse. In 1916 the police department reviewed the cases of well-known Polish public figures and large landowners, suspecting them in cooperation with Austria. In Podil, Count Henryk Grocholski, after secret surveillance by the police, was accused of a disloyal attitude to Russia, and as a result, according to Article 23 of the Rules of the area, under martial law, was evicted from the territory for the whole period of hostilities. ${ }^{28}$

The Volyn nobleman Sygismund Soberzański, a manager of housekeeping in the central estate of Count Potocki, in February 1916, was accused of cooperating with the managing folwark Ivan Skrobaczewski, who was accused of military espionage and deported from Russia. ${ }^{29}$

The staff of the Uman hospital was charged of spreading anti-government ideas, where Uman-Lypovets agricultural society arranged Polish sick quarters. Two doctors Matilda Piotrowska and Maria Werner, senior nurse Kazimierza Gruszkiewicz and the rest of the staff were Poles. According to patients, they were hostile towards all Russian and therefore tried to take to treat only ill Poles or wounded Austrians. The hospital was considered to be a centre of anti-Russian propaganda. Although, because of the great service and treatment, right use of funds, the staff was left working under police surveillance. ${ }^{30}$

Transformation of social consciousness in the perception of Poles began after the bourgeois revolution of 1917 at all levels. In a society it became more common and loyal to acquire ideas of social justice. In international politics,

\footnotetext{
27 P. Mylyukov, Vospomynanyya, Moskva 1991, p. 328.

28 TsDIAK Ukrayiny, f. 1335, op. 1, spr. 2023, ark. 4.

29 TsDIAK Ukrayiny, f. 1335, op. 1, spr. 2023, ark. 67.

30 TsDIAK Ukrayiny, f. 274, op. 4, spr. 545, ark. 17.
} 
the significant role was given to the speech of President of the USA, Woodrow Wilson, to the countries that participated in World War I in January 1917, about the equality of nations. This principle became a key one in a new system of international law. These external circumstances helped Poles to consolidate around the idea of the revival of the state, and allowed them to be treated as the subject of politics, which must be agreed upon about the future conditions of their existence.

\section{Conclusions}

Thus, the change in the perception of the image of a Pole as disloyal to Russian statehood into the image of a true ally in the fight with common enemy happened. The vision of the Polish population in the Russian Empire as dependent people changed into the perception of a people capable for independent life, and these changes took place particularly in terms of the global crises during the World War I.

The desire of Poles to restore statehood through the uprising that took place in the 19thcentury; the struggle to maintain political and economic influence in the Empire; emphasizing their cultural identity; the expression of Polish patriotism in everyday life in Russian society, including in Ukrainian lands where the number Poles was the largest, created the image of 'the enemy'. Anti-Polish, Russification policy caused different directions and trends of Polish public life. The Polish political parties which appeared in the early 20th century, despite different methods and ways, all except the left socialist direction, set the task to unit all Poles, to obtain self-government and restore statehood.

Poles supported the Russian government in the war with great enthusiasm. This support was based on the statement that Slavs must unite against Germanism and the Russian proclaimed policy of granting autonomy to the Poles. Polish elite groups announced their support to Russia, gave financial help and created and maintained hospitals and sick quarters. Many Poles came to the Russian army, conducted wide public charitable work in the cities, forming organizations assisting Polish victims in the war. The war, as well as the unification of Russians and Poles, in the struggle against a common enemy eventually created the image of "Pole-friend" in society.

With the tightening of war, huge material and human losses, the Warsaw occupation by the Germans, a large number of refugees from these areas, 
delaying solution of the Polish issue in Russia, giving by the Germans in occupied territories the right to self-government and to use the Polish language at schools and universities, all these eventually changed the mood of the Poles and led to an understanding for the struggle for independence. The perception of Poles as partners in state-building and international co-existence was possible only because of global geopolitical change, the policy of powerful countries, which included Polish territories, and the ability of Polish political forces to unite around the idea of restoration of their statehood.

The recognition of nations, which look contradictory in status, goals, tasks and mentality, is possible on the basis of strategic interests, fundamental values and conditions caused by new external crisis circumstances.

\section{Bibliography}

Bovua D., Bytva za zemlyu v Uskrayini 1863-1914 rr.: Polyaky v sotsio-etnichnykh konfliktakh, Kyyiv 1998.

Bylski L., Rzut oka na kwestię polską w dobie obecnej, Krakow 1910.

Chmielewski J., Pierwshe lata korporacji studentów polaków w Kijowie (1884-1892), Warszawa 1939.

Kalakura O., Polyaky v etnopolitychnykh protsesakh na zemlyakh Ukrayiny u XX st., Kyyiv 2007.

Korczynski J., Troche wspomnień z Żytomirza, „Pammiętnik Kijowski”, T. 2., Londyn 1963.

Korzeniowski M., Za Złotą Bramą: działalność spoleczno-kulturalna Polaków w Kijowie w latach 1905-1920, Lublin 2009.

Łobanowska M., Kotmene ogranicheniy dlya polyakov, „ZHizn’ Volyni”, 56 (1916), S. 3. (p. 3.)

Łobanowska M., Krupnyiy zemlevladelets Podolii, „ZHizn’ Volyni”, 202 (1914), S. 3. p. 3.

Mylyukov P., Vospomynanyya, Moskva 1991.

Paszkowski E., Nieporozumienie stale, „Dziennik Kijowski”, 211 (1916), S. 1-2. S. 1-2. p. 1.

Łobanowska M., Otvet polyakov na vozzvanye Verkhovnoho Hlavnokomanduyushcheho, „ZHizn’ Volyni” 8 (1914), S. 1. p. 3.

Łobanowska M., Polyaky y voyna. Zayavlenye pol'skykh party, „ZHizn’ Volyni”, 206 (1914), p. 3.

Łobanowska M., Torzhestvennoe molebstvye v rymsko-katolycheskom kafedral'nom sobore, „ZHizn’ Volyni”, 201 (1914). S. 3.

Tsentral'nyy derzhavnyy istorychnyy arkhiv Ukrayiny, m. Kyyiv, (dali TsDIAK Ukrayiny) f. 442, op. 821, spr. 291, ark. 49-53. 
TsDIAK Ukrayiny, f. 274, op. 1, spr. 3134, ark. 18-45.

TsDIAK Ukrayiny, f. 274, op. 1, spr. 2441, ark. 364.

TsDIAK Ukrayiny, f. 274, op. 4, spr. 456, ark. 80.

TsDIAK Ukrayiny, f. 274, op. 4, spr. 545, ark. 17.

TsDIAK Ukrayiny, f. 274, op. 5, spr. 56, ark. 82.

TsDIAK Ukrayiny, f. 278, op. 1, spr. 26, ark. 318.

TsDIAK Ukrayiny, f. 442, op. 864, spr. 234, ark. 1-5.

TsDIAK Ukrayiny, f. 442, op. 864, spr. 239, ark. 301.

TsDIAK Ukrayiny, f. 1335, op. 1, spr. 2023, ark. 4.

1905 r. w Polsce: zbiór artykulów, Moskwa 1926.

Urszyn J., Wojna i polska sprawa, „Klosy Ukrainskie” 9-10 (1914), S. 9-10.

Łobanowska M., Zajavlenie polyakow, „ZHizn’ Volyni”, 18 (1916), S. 3. 